\title{
TUNGAU DEBU RUMAH YANG DITEMUKAN \\ DI KELURAHAN TITIWUNGEN SELATAN KECAMATAN SARIO \\ KOTA MANADO
}

\author{
${ }^{1}$ Imelda Worang \\ ${ }^{2}$ Angle Sorisi \\ ${ }^{3}$ Victor D. Pijoh
}

\author{
Kandidat Skripsi Fakultas Kedokteran Universitas Sam Ratulangi ${ }^{1}$, \\ Bagian Parasitology Fakultas Kedokteran Universitas Sam Ratulangi \\ Manado ${ }^{2}$. \\ Email: imeldaworang@ymail.com
}

\begin{abstract}
Abstrak: Debu merupakan gabungan dari bermacam-macam partikel yang menyebar di udara, termasuk spora jamur, serbuk sari, serat pakaian, bagian tumbuhan yang telah membusuk, sisa pembakaran, tanah, dan sebagainya. Tungau debu atau dust mite, merupakan binatang sejenis kutu yang ukurannya sangat kecil, 250 - 300 mikro, sehingga tidak kasat mata. binatang ini baru terlihat di bawah mikroskop dengan pembesaran setidaknya 20 kali. Bentuk badannya lonjong dengan kaki berjumlah 8 buah. Alergen TDR adalah salah satu patogen yang paling penting yang menyebabkan alergi pada asma. Metode penelitian inbersifat survey deskriptif yang dilakukan secara cross sectional pada bulan Oktober sampai Desember 2012 di Kelurahan Titiwungen Selatan Kecamatan Sario Kota Manado. Hasil penelitian mendapatkan 5 jenis spesies tungau debu rumah yaitu: Dermatophagoides spp. Glycyphagus destructor. Cheyletus spp, Acarus spp, Tarsonemus spp. Kesimpulan Jenis Tungau debu rumah paling banyak ditemukan baik di ruangan keluarga maupun ruangan tidur yaitu Acarus spp. Tungau debu rumah lebih banyak ditemukan pada ruang tidur dibandingkan ruangan keluarga, dan dimana kepadatan TDR di kelurahan titiwungen cukup rendah.
\end{abstract}

Kata kunci: Acarus spp, Dermatophagoides, Tungau Debu

Abstract: Dust is a combination of a variety of air-borne particles, including mold spores, pollen, clothing fibers, decomposing plant parts, combustion, soil, and so on. Dust mites, fleas are the kind of animal with very small size 250-300 micro, so it is not visible. This new animal looks under the microscope with magnification at least 20 times .Oval body shape with the legs are 8 pieces. TDR allergens is one of the most important pathogens that cause 
asthma allergic. The research method used is cross-sectional descriptive survey, where the survey is done from October until December 2012 in South Titiwungen neighborhood, Sario region Manado. The results get 5 different species of house dust mites are: Dermatophagoides spp, Glycyphagus destructor, Cheyletus spp, acarus spp, Tarsonemus spp. Conclusions Type of house dust mites most commonly found either in the family or the bed room acarusspp. House dust mites are more common in the bedroom than the family room and where the density of TDR in the village Titiwungen quite low.

Keywords : acarusspp , Dermatophagoides , Dust Mites

Debu merupakan gabungan dari bermacam-macam partikel yang menyebar di udara, termasuk spora jamur, serbuk sari, serat pakaian, bagian tumbuhan yang telah membusuk, sisa pembakaran, tanah, dan sebagainya. Namun di rumah, selain berasal dari polusi luar rumah, umumnya debu berasal dari sisa makanan, lapisan kulit luar manusia yang mengelupas, bulu hewan peliharaan seperti anjing atau kucing, dan sebagainya. ${ }^{1}$

Di dalam debu rumah terdapat tungau debu rumah (TDR) yang banyak ditemukan pada perabot-perabot rumah. Tungau debu rumah dapat menjadi masalah yang serius bagi kesehatan manusia $^{2}$

Tungau debu atau dust mite, merupakan binatang sejenis kutu yang ukurannya sangat kecil, 250 - 300 mikro, sehingga tidak kasat mata. binatang ini baru terlihat di bawah mikroskop dengan pembesaran setidaknya 20 kali. Bentuk badannya lonjong dengan kaki berjumlah 8 buah. ${ }^{3}$ Alergen TDR adalah salah satu patogen yang paling penting yang menyebabkan alergi pada asma. ${ }^{4}$

Kepadatan populasi TDR yang terdapat di dalam kasur selain dipengaruhi oleh jenis kasur, suhu dan kelembaban juga dipengaruhi oleh berbagai hal lain seperti masa penggunaan kasur, ketebalan kasur, serta frekuensi, cara, dan alat yang digunakan untuk membersihkannya. ${ }^{5}$
Kanthawatana et al (1997) pada penelitiannya di Thailand mengemukakan bahwa spesies Dermatophagoides pteronyssinus adalah TDR yang paling sering ditemukan dan TDR merupakan salah satu alergen inhalan yang paling sering dijumpai di dunia. ${ }^{6}$

Berdasarkan paparan diatas, maka penulis akan melakukan penelitian tentang: Bagaimana kepadatan dan jenis Tungau Debu Rumah yang ada diKelurahan Titiwungen Selatan Kecamatam Sario Kota Manado?

\section{METODE PENELITIAN}

Metode penelitian ini ialah bersifat survey deskriptif yang dilakukan secara cross sectional. Penelitian ini dilakukan pada bulan Oktober 2012 sampai desember 2012. Pengambilan sampel di Kelurahan Titiwungen Kecamatan Sario Kota Manado.

Identifikasi tungau debu dilakukan di laboratorium Parasitologi Fakultas Kedokteran Unsrat. Populasi pada penelitian adalah seluruh rumah di Kelurahan Titiwungen Kecamatan Sario Kota Manado. Sampel pada penelitian adalah Sampel penelitian berupa debu yang dikumpulkan dari kasur dan lantai ruang tidur serta perabot dan lantai ruang keluarga pada rumah Kelurahan Titiwungen Selatan Kecamatan Sario Kota 
Manado menggunakan metode Simple Random sampling.

Besar sampel, Jumlah sampel rumah/bangunan yang akan di periksa di hitung berdasarkan rumus besar sampel ditentukan dengan menggunakan rumaus Snedecor Cochran :

Ket :

$$
n_{1=\frac{4 x p x q}{L^{2}}}
$$

$\mathrm{n}_{1}=$ besar sampel pada tahap pertama

$\mathrm{p}=$ Prosentase taksiran hal yang akan di teliti

$q=100-p$

$\mathrm{L}=$ Galat/tingkat erorr

$$
n_{1=\frac{4 \times 95 \times 5}{25}}=76
$$

Terhadap nilai $n_{2=\frac{n_{1}}{1+\frac{n_{1}}{N}}}$

Ket :

$\mathrm{N}=$ jumlah populasi referens

$$
n_{2=\frac{76}{1+\frac{76}{452}}}=65
$$

Variabel penelitian pada penelitian ini adalah 1)Debu Rumah, 2)Tungau debu rumah, 3)Jenis tungau debu rumah, 4)Kepadatan TDR.

\section{HASIL PENELITIAN}

Tabel 1. Jumlah rumah yang positif tungau debu

\begin{tabular}{rr}
\hline Periksa & Posiif \\
\hline
\end{tabular}

Jumlah

Dari tabel 1. Terlihat bahwa dari 71 rumah yang diperiksa, hanya 61 rumah yang positif Tungau Debu.

Tabel 2.Jumlah ruangan keluarga dan ruangan tidur yang positif tungau debu

\begin{tabular}{llr}
\hline $\begin{array}{l}\text { Ruanganyang } \\
\text { diperiksa }\end{array}$ & Periksa & Positif \\
\hline Ruang keluarga & 71 & 42 \\
Ruang tidur & 71 & 46 \\
\hline
\end{tabular}

Dari tabel 2, terlihat bahwa dari 71 ruangan keluarga yang diperiksa, hanya 42 ruangan keluarga yang positif Tungau Debu. Begitu juga dengan ruangan tidur dari 71 ruangan yang di periksa hanya mendapatkan 46 ruangan tidur yang positif tungau debu.

Table 3. Jenis tungau debu yang terdapat di ruangan keluarga dan ruangan tidur

\begin{tabular}{lllllll}
\hline \multicolumn{1}{c}{ Jumlah Tungau } \\
\hline \multicolumn{1}{c}{ Spesies } & R. Keluarga & $\%$ & R. Tidur & $\%$ & Total & $\%$ \\
$\begin{array}{l}\text { Dermatophagoides } \\
\text { spp }\end{array}$ & 6 & 5 & 9 & 7 & 15 & 12 \\
Glycyphagus & 10 & 8 & 18 & 15 & 28 & 23 \\
Cheyletus spp & 1 & 0,8 & 1 & 0,8 & 2 & 1 \\
Acarus spp & 25 & 21 & 27 & 22 & 52 & 44 \\
Tarsonemus & 10 & 8 & 11 & 9 & 21 & 17 \\
Jumlah & 52 & 43 & 66 & 54 & 118 & 100 \\
\hline
\end{tabular}

Dari tabel 3, terlihat bahwa Tungau debu jenis Acarus spp yang mempunyai presentasi terbesar di ruangan tidur dan ruangan keluarga.

Tabel 4, Jumlah rata-rata kepadatan tungau debu

Ruang Tidur Ruang Tamu

$\begin{array}{lll}\text { Rata-Rata } & 1,83 & 1,80\end{array}$

Dari tabel 4, terlihat bahwa kepadatan tungau diruang tamu pada 0,1 gram debu adalah 1,80 dan kepadatan diruan tidur adalah 1,83 .

\section{PEMBAHASAN}

Dari hasil penelitian yang dilkukan (tabel 1) dilihat bahwa ada beberapa rumah yang positif tungau, dari 71 rumah yang di periksa hanya mendapatkan 61 rumah yang positif tungau. Hal ini disebabkan karena dalam saat penelitian berlangsung banyak rumah terlihat jarang dibersihakan 
dan juga pada saat penelitian diadakan dalam keadaan musim hujan, jadi jumlah tungau debu yang didapat lumayan banyak dan juga ada beberapa rumah yang bebas dari tungau. Hadi S 2002 dia menyatakan bahwa pada daerah yang kumuh dan padat penduduk akan menyebabkan lingkungan kurang baik dan dapat menyebabkan suhu ruangan menjadi panas dan lembab sehingga tungau bisa dapat berkemban gbiak dengan cepat. ${ }^{7}$

Dari hasil penelitian pada (tabel 2) ini dimana telah mendapatkan beberapa ruangan yang positif baik itu ruangan tidur maupun ruangan tamu, dari 71 ruangan tidur yang diperiksa hanya mendapatkan 46 ruangan yang positif tungau debu, sedangkan ruangan keluarga hanya mendapatkan 42 ruangan yang positif tungau debu. Jadi dari kedua ruangan ini yang lebih banyak ditemukan tungau debu yaitu pada ruangan tidur, hal ini disebabkan karena orang-orang lebih lama berada pada ruangan tidur dari pada ruang keluarga, waktu seseorang dikamar tidur bias mencapai rerata 6-8 jam dan hal ini sangat mempengaruhi populasi dari TDR ini. Populasi dari TDR sangat bergantung dari asupan makanannya dalam hal ini adalah serpihan kulit manusia.

Dari hasil penelitia (tabel 3). Begitu juga dengan ruang tidur, yang mendominasi adalah spesies Acarus spp $22 \%$ tabel 3. Berdasarkan data tersebut dapat dikatakan tungau yang paling mendominasi di Kelurahan Titiwungen selatan Kecamatan Sario yaitu spesies Acarus spp. Hasil diatas berbeda dengan penelitian yang dilakukan oleh Aulung A, dkk, 1987 di Jakarta menemukan frekwensi sebaran tungau debu rumah Glycyphagus destructor $47,7 \%$ yang paling tinggi, kemudian Cheyletus eruditas $41,6 \%$ sedangkan presentasi frekwensi sebaran Dermatophagoides spp. Menempati urutan ketiga 22,9\%. ${ }^{8}$
Dari hasil penelitian kepadatan tungau debu rumah, (tabel 4) berdasarkan hasil pengukuran didapatkan berat rerata TDR per 0,1 gram debu ruang tamu adalah 1,80 dan ruang tidur adalah 1,83. Kepadatan TDR per $\mathrm{m}^{2}$ dari ruang tidur lebih tinggi dari pada ruang tamu. Hal ini dapat disebabkan oleh karena perbedaan suhu dan dimana suhu kelembaban diruang tidur relative lebih tinggi dari pada ruang tamu serta kebanyakan orang menghabiskan 6-8 jam diruang tidur, hal ini sangat mempengaruhi asupan makanan dari TDR sendiri. Jika dibandingkan penelitian yang dilakukan oleh Hadi S (2002) di dapatkan rerata jumlah tungau debu rumah per 0,1 gram debu kasur adalah 2,6. Angka ini lebih tingi dibandingkan dengan hasil penelitian yang diperoleh. ${ }^{7}$

\section{KESIMPULAN}

Jenis Tungau debu rumah paling banyak ditemukan baik di ruangan keluarga maupun ruangan tidur yaitu Acarus spp dan tungau debu rumah lebih banyak ditemukan pada ruang tidur dibandingkan ruangan keluarga dari hasil kepadatan TDR di kelurahan titiwungen cukup rendah.

\section{UCAPAN TERIMAKASIH}

Penulis menyadari bahwa penyusunan artikel ini tidak lepas dari bantuan dan bimbingan dari dosen pembimbing. Oleh karena itu, penulis mengucapkan terima kasih kepada dr. Angle Sorisi, M,Sc dan dr. Victor D. Pijoh, Mkes selaku dosen pembimbing. Penulis juga berterima kasih kepada semua pihak yang secara langsung maupun tidak langsung membantu menumbuhkan ide dalam penulisan artikel ini. 
DAFTAR PUSTAKA

1. Vitahealth.Asma-Infromasi Lengkap untuk Penderita dan Keluarga.Jakarta: Gramedia Pustaka Utama. h.47-48. 2005

2. Faiza, A.2006. Hubungan Antara Lama Penggunaan Kasur Kapuk dengan Jumlah Populasi Tungau Debu Rumah di Perumahan PJKA Kelurahan Randusari. (Skripsi) Semarang: Universitas Diponegoro. 2006

3. Aruralmy. Bahaya tungau debu rumah.[updated2009 Oktober 24; cited 2012 Okt 18]Available from: http://www.wordpress.com/2009/10/ 24.html

4. Feng M, Bing Y, Yijun Z, Yanagi U, Xunjia C.A Study on Indoor Environment Contaminants Related to Dust Mite in Dwellings of Allergic Asthma Patients and of
Healthy Subjects. BioScience Trends; 2012, 6(1),7-9

5. Yudopranoto K. Perbandingan Populasi Tungau Debu Rumah pada Kasur Kapuk dan Non-Kapuk di Perumahan PJKA Kelurahan Randusari Semarang Selatan Jawa Tengah. [Skripsi].

Semarang:Universitas

Diponegoro,2006

6. Pedoman Pengendalian Penyakit Asma, Keputusan Mentri Kesehatan Republik Indonesia 2008.

7. Hadi,S. Hubungan Kepadatan Tungau Debu Rumah dengan Derajat Penyakit dermatitis Atopik.2002

8. Sungkar,S. Aspek Biomedis Tungau Debu Rumah. Maj Kedokteran Indonesia, Volume: 54, Nomor: 6, Juni 2004 